\title{
A Farewell to Arms? US Security Relations with Taiwan and the Prospects for Stability in the Taiwan Strait
}

\author{
Ping-Kuei Chen, Scott L. Kastner, and William L. Reed
}

Continued US security ties with Taiwan, and in particular US weapons sales to the island, have long been a source of tension in the US-China relationship. The People's Republic of China (PRC) found it unacceptable that Washington insisted on selling weapons to Taiwan even after US-PRC normalization in 1979; the Taiwan Relations Act, which contained explicit references to continued US arms sales to Taiwan, further angered Chinese leaders. ${ }^{1}$ Washington agreed in a 1982 communiqué "to reduce gradually its sale of arms to Taiwan" and promised that future arms sales to Taiwan "would not exceed, either in qualitative or quantitative terms," those of recent years, ${ }^{2}$ but the record of US arms sales since suggests that the communiqué has had little constraining effect on US behavior. ${ }^{3}$ US arms sales to Taiwan, in turn, often provoke an angry Chinese response, which typically includes tough rhetoric and symbolic retaliation, such as temporarily suspending US-China military-tomilitary dialogues. ${ }^{4}$ US arms sales to Taiwan have continued to generate frictions in US-China relations even though relations between Taipei and Beijing improved dramatically after the 2008 election of Ma Ying-jeou as president in Taiwan. In early 2010, for instance, PRC officials were "strongly indignant" after an arms sale announcement, calling the sale a "gross intervention in China's internal affairs" that would have a "serious negative impact" on bilateral relations. ${ }^{5}$

As China's rapid rise as an economic and-increasingly-military power dramatically alters the security landscape in East Asia, however, prominent voices in both Washington and Beijing have in recent years advocated a shift in their respective countries' approach to the US-Taiwan relationship. In the United States, several scholars and former officials have called for a reduced US security commitment to Taiwan and in particular an end to arms sales to Taiwan. Proponents 
of this view suggest that a scaled-back US commitment would pay dividends in terms of an improved US-China relationship. In the PRC, meanwhile, a number of voices have called for a tougher Chinese response to US arms sales-including the imposition of economic sanctions. Advocates of a tougher approach suggest that a willingness to retaliate more strongly would force the United States to reconsider its commitment to Taiwan. This chapter critically evaluates both proposed policy shifts. In the pages that follow, we present a simple framework for thinking through the broader implications of US arms sales for the cross-Strait relationship. We use the framework, in turn, to shed light on how changes in US or PRC policy on the arms sales issue could affect the prospects for stability in cross-Strait relations and the nature of bargaining between China and Taiwan. Our key conclusion is that both proposed policy shifts - a reduction in US arms sales to Taiwan and a tougher PRC response to arms sales-carry with them significant risks (some counterintuitive) for the country that would initiate the change.

First, we show that a decision to terminate US arms sales to Taiwan could destabilize cross-Strait relations in ways not fully appreciated in existing studies. In particular, a reduced US commitment to Taiwan could help transform the basic structure of cross-Strait relations from a deterrence dynamic to a compellence dynamic. But we qualify our argument by emphasizing that ending arms sales to Taiwan could have other, stabilizing effects and that under the right circumstances such a shift in US policy could actually reduce the likelihood of military conflict in the Taiwan Strait. Second, we show that a tougher PRC response to US arms sales could reveal a stronger US commitment to Taiwan than was previously evident; Taiwan, in turn, would have more leeway to pursue nonaccommodating policies toward Beijing. In other words, both proposed policy adjustments would carry a significant risk of backfiring, as they would risk producing outcomes completely antithetical to the original intent of the policy shift. We emphasize throughout that these counterintuitive outcomes would not necessarily arise but that they are real possibilities that should induce caution in both Washington and Beijing.

The next section gives a brief overview of the recent debate in the United States concerning the US security relationship with Taiwan. We then sketch a simple model of cross-Strait relations and use the model to evaluate the likely consequences of a US decision to terminate arms sales to Taiwan. Next, we consider calls in Beijing to take a tougher stance on US arms sales to Taiwan and how such a shift in PRC policy might affect cross-Strait relations. We conclude with some brief policy recommendations.

\section{SAYING “GOODBYE” TO TAIWAN? THE RECENT \\ US DEBATE}

Given the tensions - and the anger in Beijing — that are generated by US arms sales to Taiwan, some in the United States propose that Washington end (or at least 
scale back) weapons sales to the island. Doing so, proponents suggest, would remove a major irritant in the US-China relationship and would increase trust and cooperation in bilateral relations. ${ }^{6}$ More fundamentally, proponents of a reduced US commitment to Taiwan suggest that such a policy approach would help lower the risk of armed conflict in East Asia. This argument is developed most fully by Charles Glaser, 7 who suggests that ending the US commitment to defend Taiwan would bring with it two significant benefits for the US-China relationship. First, it could improve US-China relations because such a shift in US policy would remove a key source of mistrust in Beijing concerning US motivations. Second, ending US support for Taiwan-by removing the key potential source of military conflict between China and the United States-would reduce military competition between Washington and Beijing. Glaser thus proposes a "grand bargain," in which the United States would end its commitment to Taiwan in return for Chinese willingness to "resolve its maritime disputes on 'fair' terms" and to accept a long-term US security presence in East Asia. Others argue that the US commitment to Taiwan is increasingly untenable as China's military power continues to grow. For instance, Chas Freeman warns that a continued US commitment to Taiwan is incompatible with (a) waning US relative power in the region and (b) the importance that the PRC places on the issue. A failure to accommodate US policy to new geopolitical realities, in turn, risks future military conflict over an issue about which China cares deeply. ${ }^{8}$ John Mearsheimer argues along similar lines that China's rise as a great power, if it continues, will mean that the current US security commitment to Taiwan will be increasingly unsustainable. Taiwan will ultimately be forced to accommodate growing Chinese power. ${ }^{9}$

Proposals to scale back US security ties to Taiwan are controversial, however, and several scholars have written thoughtful critiques of the idea. These critiques have generally made a few key points. First, it is not self-evident that ending security ties with Taiwan would in fact transform the US-China relationship: the interests of the two countries arguably clash on many other issues (North Korea, maritime disputes in East Asia, economic issues), and it is unclear why Beijing would yield on these other issues if only the United States were to adopt a policy on arms sales that-from Beijing's vantage-the United States had already committed to follow in the 1982 joint communiqué. Second, the United States' reputation in the region could be at stake. Some worry that walking away from a commitment to Taiwan would send a troubling signal to other US allies in East Asia. Beijing might likewise view US concessions on Taiwan as a sign of weakness and conclude that Washington was unlikely to challenge the PRC on other issues in the region. Third, ending arms sales-because it would add to Taiwan's sense of insecurity-could actually make Taipei more hesitant about entering into sensitive political talks with the PRC; thus it isn't clear that a reduced US commitment to Taiwan would facilitate a peaceful resolution to the dispute. Finally, and relatedly, ending arms sales would likely undercut Taiwan's 
deterrent capabilities, which in turn could encourage a more coercive PRC approach to the island. ${ }^{10}$

While we find these counterarguments plausible, we believe the logic underpinning them needs to be teased out at greater length. This is especially so for claims about the prospects for stability in the Taiwan Strait. For instance, we believe it is likely that an end to arms sales would indeed lead Taiwanese officials to feel less confident about their bargaining power vis-à-vis the PRC. But it is not obvious why this should in itself make them less likely to negotiate with Beijing: it is also plausible that, in such a scenario, Taiwan's leaders would feel they had no other choice but to negotiate with an increasingly powerful PRC. Similarly, while a shift in the cross-Strait balance of power would indeed imply that Beijing could more easily utilize a military option, it isn't obvious that this would in turn make the relationship less stable: it is conceivable, for instance, that Taiwan would respond with more accommodating policies that would remove Beijing's incentives to consider military force. In short, how a shifting cross-Strait military balance of power would affect stability in the Taiwan Strait is not straightforward; in the following section, we consider the topic more systematically.

\section{RETHINKING THE IMPLICATIONS OF ENDING ARMS SALES TO TAIWAN}

In this section, we argue that ending the US security commitment to Taiwan - and in particular ending US arms sales to Taiwan-could be destabilizing. As others have noted, ending US arms sales would likely have a significant effect on the balance of power in the Taiwan Strait. We suggest that a sharp shift in the balance of power could alter the nature of cross-Strait bargaining, potentially transforming PRC-Taiwan relations from a deterrence relationship to a compellence relationship. This, in turn, could raise the risk of military conflict, for reasons that we detail.

We also emphasize, however, that US arms sales to Taiwan (and the broader US-Taiwan relationship) represent only one of many factors that influence Beijing's expected costs of conflict in the Taiwan Strait. If other factors cause Chinese leaders to perceive those costs of conflict to be sufficiently high, then even large shifts in the cross-Strait balance of power will not be destabilizing. Indeed, reduced arms sales could increase Beijing's expected costs of conflict. For instance, to the extent that proponents of reduced arms sales are right that such a policy shift in Washington will lead to improved relations with Beijing, it could give the PRC a greater stake in a stable US-China relationship - which would, presumably, be undermined by PRC initiation of military conflict against Taiwan.

The implications of ending arms sales to Taiwan for stability in the Taiwan Strait, in short, are not straightforward. Rather, drawing conclusions in this regard 
requires careful identification and analysis of the specific causal processes through which arms sales affect stability in the Taiwan Strait. We aim to undertake this sort of analysis by constructing a simple model of cross-Strait relations. We then consider how US arms sales to Taiwan affect key parameters in the model and how ending those sales would affect the likelihood of conflict.

\section{A SIMPLE MODEL OF CROSS-STRAIT RELATIONS}

The key dispute between the PRC and Taiwan concerns Taiwan's sovereign status. The PRC claims sovereignty over Taiwan and rejects the notion that the Republic of China (ROC) government on Taiwan represents an independent, sovereign state. For Beijing formal unification with the island remains an important national objective. Thus any effort on Taiwan that tries to weaken the political and historical link between Taiwan and mainland China provokes opposition in Beijing; the PRC refuses to renounce the use of force against Taiwan and has vowed to fight a war to prevent Taiwan's formal separation from China. Taiwan's position on the sovereignty issue, meanwhile, has evolved considerably over time. For several decades following the Nationalist retreat to Taiwan, the ROC government continued to view itself as the legitimate government of all of China; the PRC, in turn, was a "bandit" regime that lacked legitimacy. As Taiwan democratized in the 1980s and 1990s, however, its government began to distance itself from the notion that both sides of the Taiwan Strait were parts of "one China." Under President Lee Teng-hui's "pragmatic diplomacy," Taiwan sought greater participation in international society as a political entity separated from PRC. Lee floated concepts such as "one China, two political entities," and in 1999 described the cross-Strait relationship as "state-to-state, or at least special state-to-state relations." President Chen Shui-bian (2000-2008) later took numerous symbolic steps to highlight Taiwan's separateness from China. Chen often described Taiwan as an "independent, sovereign country," and during his presidency he advocated a new constitution more "suitable" to the needs of Taiwan than the ROC constitution (which predated the Nationalist retreat to the island). Cross-Strait relations were often tense during the Lee and Chen presidencies, and Beijing frequently warned that it was willing to use force to prevent Taiwan from formalizing its independent status.

The relationship between China and Taiwan stabilized considerably after the election of Ma Ying-jeou as Taiwan's president in 2008. Ma articulated a "three nos policy" of no independence, no unification, and no use of force while he was president, and he pursued (with considerable success) cooperation with the PRC in functional areas such as trade, investment, tourism, and extradition. But whereas Ma was more accommodating than his predecessors on sovereignty issues, the fundamental question of Taiwan's status remained unresolved. Progress on this front appears unlikely in the foreseeable future: Ma's successor, Tsai Ing-wen of the 
Democratic Progressive Party, has been less accommodating on sovereignty issues than Ma, and the post-20o8 détente in cross-Strait relations has largely evaporated. The relationship across the Taiwan Strait, in short, remains untransformed at its core, reflecting continuing disagreement over Taiwan's sovereign status.

We assume, then, that Taiwan's sovereign status is the principal issue over which the PRC and Taiwan are (explicitly or implicitly) bargaining. For simplicity, we assume that Taiwan's status can be represented on a single dimension ranging from formal unification with China (U) at one extreme to a formally independent Taiwan (I) on the other (see figure 11). ${ }^{11}$ Assume further that Taiwan's leadership prefers an outcome closer to I and China's prefers an outcome closer to U, and assume that China's utilities range from o for formal independence to 1 for unification. ${ }^{12}$ The preferences of the PRC and Taiwan for unification or independence are strictly opposed and linear. In our model, we assume a status quo point lying somewhere between $U$ and I, and we assume that Taiwan may at any given time propose a different status quo. The PRC can either tolerate the new status quo as defined by Taiwan or try to impose its most preferred outcome (U) through force. Assume that if the two sides were to fight a war, China would prevail with probability $\mathrm{p}$ and that victory would enable Beijing to impose its preferred outcome of unification on Taiwan. ${ }^{13}$ Finally, assume that the expected utility each side would reap from the war outcome would be reduced by the costs of actually fighting the war, represented by $c_{c}$ for China. China's expected utility for war thus is $\mathrm{p}-$ $\mathrm{c}_{\mathrm{c}}$, which is represented by point $\mathrm{R}$ in figure 11 . $\mathrm{R}$ represents the PRC's reversion point: so long as Taiwan chooses a level of sovereign status to the right of $\mathrm{R}$, then the PRC prefers to tolerate that status. But if Taiwan chooses a status to the left of $\mathrm{R}$, then the PRC prefers to initiate military conflict. War, of course, would be tremendously costly for Taiwan, so Taiwanese leaders have strong incentives to choose a level of sovereign status to the right of R. R, in other words, defines the best outcome Taiwan can hope to achieve.

Regarding the prospects for instability in the Taiwan Strait, the most likely scenario for a cross-Strait conflict typically given by analysts of the China-Taiwan relationship has involved a "revisionist" Taiwan trying to formalize its independent status (or taking steps in that direction), thus triggering a PRC military response. ${ }^{14}$ A president strongly committed to formalizing Taiwan's status as an independent country might, for instance, engineer a change in the island's official name (to the Republic of Taiwan) or push through a new constitution written specifically for Taiwan. In terms of figure 11, war could arise in this scenario if the new status quo lay to the left of China's reversion point, R. Why would Taiwan cross such a red line, given the high costs it would undoubtedly pay if war were to erupt with the PRC? If Taiwan could know with certainty where R actually lay, it would choose a level of sovereign status just to the right of $\mathrm{R}$ and leave it at that. Unfortunately, Taiwan cannot know with certainty where $\mathrm{R}$ actually sits because it cannot know 


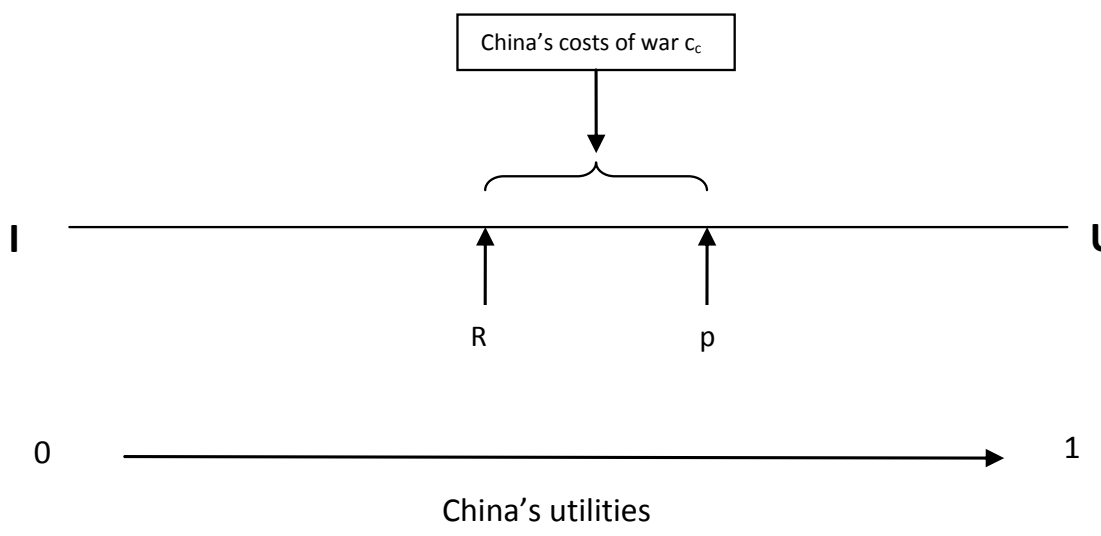

FIGURE 11. A model of cross-Strait relations.

with certainty how China assesses $\mathrm{p}$ and $\mathrm{c}_{\mathrm{c}}$. Moreover, it is difficult for Beijing to reveal this information credibly to Taiwan, since the PRC has clear incentives to overstate its power and resolve so as to convince Taiwan's leadership that $\mathrm{R}$ lies farther left than might truly be the case. Taiwan, in turn, surely knows that Beijing has incentives to bluff. ${ }^{15}$

In recent decades, then, the cross-Strait relationship has been characterized primarily by a problem of deterrence, where the PRC tries to deter Taiwan from taking steps toward formal independence but where there may be some uncertainty in Taiwan concerning how credible these deterrent threats are. The centrality of deterrence was most clear under the Lee and Chen administrations: both presidents aimed to redefine Taiwan's relationship with the PRC in a way that was antithetical to Beijing's ideal point of ultimate reunification. The PRC, in turn, sought to deter Taiwan from pushing too far on sovereignty issues by signaling its willingness to use force to stop Taiwan independence. Examples here include the PRC's escalating series of military exercises conducted after Lee Teng-hui visited Cornell University in 1995, its 2000 white paper warning that it would not wait indefinitely on national unification, frequent assertions during the Chen administration that the PRC was prepared to "pay any costs" to prevent Taiwan independence, and the passage of the 2005 antisecession law. After the election of Ma Ying-jeou in 2008 , the relationship stabilized greatly: Ma did not push sovereignty issues to the same degree as his predecessors, and Chinese leaders consequently did not need to signal opposition to Taiwan independence as forcefully as before. But deterrence remains central to the relationship. Indeed, the PRC threat to use force appears to be the primary reason support for independence is not more widespread among Taiwan's voters in the first place. ${ }^{16}$ And now that the Democratic Progressive Party 
has returned to power in Taiwan, it is quite likely that the PRC deterrent threats will again become more frequent and pronounced.

\section{WHY ENDING US ARMS SALES TO TAIWAN COULD BE DESTABILIZING}

How would a reduced US security commitment to Taiwan affect the likelihood of cross-Strait conflict? More concretely, what would happen if the United States were to terminate arms sales to the island? Remember that in our simple model conflict occurs if Taiwan claims a level of sovereign status to the left of point $\mathrm{R}$ on the I-U continuum. How, then, might an end to arms sales affect the probability that Taiwan's claimed status would lie to the left of point R? Here, we begin by considering the most intuitive, direct ways that changing levels of arms sales to Taiwan could affect the parameters of the model and the associated implications. In the following subsection, we consider more indirect and nonintuitive effects of ending arms sales, which in turn serve to qualify points made in this subsection.

Intuitively, it would seem that US arms sales to Taiwan directly affect both the costs $\left(c_{c}\right)$ that China would expect to pay in a cross-Strait military conflict and the probability $(\mathrm{p})$ that China would win such a conflict. On the margins at least, arms sales should improve Taiwan's military capabilities relative to those of the PRC, thereby reducing $\mathrm{p}$ and increasing $\mathrm{c}_{\mathrm{c}}$. Of course, $\mathrm{p}$ and $\mathrm{c}_{\mathrm{c}}$ are determined not simply by the balance of power between China and Taiwan but also by likely US behavior in the event of a cross-Strait war: US intervention would at a minimum greatly complicate the PRC's ability to prevail in a cross-Strait war and would certainly increase China's expected costs of such a conflict. Thus a higher likelihood of US intervention implies a smaller $\mathrm{p}$ and a larger $\mathrm{c}_{\mathrm{c}}$. Arms sales to Taiwan, in turn, may signal some level of US commitment to the island. To the extent that arms sales to Taiwan do in fact increase confidence in Beijing and Taipei that the United States is likely to intervene in a cross-Strait conflict, continued US arms sales to Taiwan imply a smaller $\mathrm{p}$ and larger $\mathrm{c}_{\mathrm{c}}$ than would be the case in the counterfactual world where the United States did not sell weapons to Taiwan.

These direct effects suggest, then, that ending arms sales should reduce China's expected costs of war and increase the probability of PRC victory; $\mathrm{R}$, in turn, should shift to the right. This makes intuitive sense: to the extent that the balance of power in the Taiwan Strait favors the PRC, we might expect Beijing to be more demanding on sovereignty issues (and less tolerant of outcomes that diverge sharply from its ideal point of unification). Were $\mathrm{R}$ to shift to the right of Taiwan's actual status, the model suggests that the PRC would prefer to fight a war rather than to accept a continuation of that status quo; military conflict would ensue if Taiwan failed to accommodate this new reality by redefining its sovereign status (i.e., to push the status 
quo back to the right of R). Given the obviously high costs of war for Taiwan-costs that would presumably be especially high in the absence of any US security commitment to the island-leaders in Taipei would have strong incentives to avoid this outcome by bowing to new power realities and accommodating the PRC on sovereignty issues to some degree.

Yet there are some reasons to think that accommodation in this regard would be difficult. Recall that in recent decades the primary strategic challenge in cross-Strait relations can be characterized as a problem of deterrence, with the PRC trying to deter Taiwan efforts to redefine its sovereign status in a way that conflicts with PRC hopes for unification. But if $\mathrm{R}$ were to shift right of the status quo, the model suggests that the cross-Strait relationship would instead be characterized by a problem of compellence. Here, a war could occur, not because the PRC fails to deter unilateral Taiwan changes to the status quo, but rather because the PRC fails to compel Taiwan to alter the status quo in a way that is more to Beijing's liking (remember that once R shifts right of the status quo, Beijing's expected war payoff exceeds its utility for a continuation of the status quo). Nevertheless, commitment problems could complicate the search for a peaceful accommodation even if Taiwan recognized that $\mathrm{R}$ had moved to the right of the status quo and even if Taiwan was in principle willing to bargain away some of its sovereignty. ${ }^{17}$ The reason is that the issue being bargained over, Taiwan's sovereign status, could affect future bargaining power between the two sides: that is, bargaining some of its sovereign status to avoid war in the short term could further diminish Taiwan's future bargaining power vis-à-vis Beijing.

Even if the United States were to stop selling arms to Taiwan and renounce any security commitment to the island, Taiwan would remain qualitatively different from areas under direct PRC control. It would continue to be self-governing and democratic, it would continue to maintain armed forces, and it would-for all intents and purposes-continue to resemble an independent country on all dimensions except international legal recognition. But Taiwan's continued otherness in this regard opens the door to possible US intervention in a cross-Strait conflict even after a US decision to end its security commitment to Taiwan. Leaders in Washington, for instance, might revise their view of the PRC, especially in the aftermath of an attack on Taiwan, and particularly if renouncing the security commitment entailed a quid pro quo PRC pledge. Thus, even after the United States ended arms sales to Taiwan and renounced a security commitment to the island, the probability of US intervention in a cross-Strait conflict would not drop to zero-in contrast to the likelihood of US intervention in other areas of China such as Tibet (or, for that matter, Hong Kong). But the more Taiwan accommodated PRC demands by allowing itself to become something more resembling Hong Kong or Tibet than an independent country, then the more the probability of US intervention would begin to approach zero as it does for other areas under direct 
PRC control. Such intervention would increasingly, and unambiguously, represent intervention in a civil, rather than an international, conflict. ${ }^{18}$

Thus any bargain involving a reduction in Taiwan's sovereignty should independently reduce Beijing's expected costs of war, thus pushing $\mathrm{R}$ even further to the right. The credibility of Beijing's commitment to such a bargain would therefore be suspect, as once it was implemented Beijing would have incentives to demand an even more favorable bargain (and Taiwan would not be in a position where it could refuse). Fearon develops a similar model where states bargain over strategic territory and the outcome of the negotiations explicitly shifts the balance of power. ${ }^{19}$ This change in the balance of power happens because the outcome of the negotiation transfers territory to a rival state and thereby improves that rival's fighting capacity. When this type of dynamic is at work, reaching a settlement becomes difficult because the consequence of the shift in power caused by a settlement may be less desirable than fighting and forgoing any negotiations. Although a hypothetical bargain between the PRC and Taiwan is not over strategic territory, it is certainly possible that a similar dynamic is at work as the PRC and Taiwan negotiate over Taiwan's sovereignty. Inasmuch as giving up sovereignty to the PRC strengthens the PRC's bargaining leverage, Taiwan may come to the conclusion that risking war is preferable to any negotiated settlement with the PRC over unification. In other words, Taiwan may conclude that it would be better to roll the dice in a war with China today than to accept the terms of an obsolescing bargain likely to result in a progressively more subordinate status within a unified China. Therefore, in the same way that bargaining over strategic territory is complicated by the strategic consequences of any deal that might be struck, bargaining over unification can be dangerous because it has implications for the future bargaining power of the PRC and Taiwan.

In summary, ending arms sales to Taiwan would have the potential to increase instability in the Taiwan Strait. Such a shift in US policy could alter the balance of power in the Taiwan Strait, which in turn could shift the strategic dynamic from deterrence to compellence. In turn, there are reasons to believe that a China-Taiwan relationship in which China tried to compel steps toward unification would be more conflict prone than one where the PRC tried to deter Taiwan steps toward independence, as credible commitment problems could make it difficult for Taiwan to accommodate new power realities.

\section{WHY ENDING US ARMS SALES TO TAIWAN WOULD NOT NECESSARILY BE DESTABILIZING}

The analysis above suggests that ending arms sales to Taiwan would be destabilizing if doing so had enough of an effect on $\mathrm{p}$ and $\mathrm{c}_{\mathrm{c}}$ to push $\mathrm{R}$ to the right of the 
status quo. However, there are reasons to question whether ending sales would indeed have such a large effect. On the one hand, as the balance of power in the Taiwan Strait continues to shift in China's favor, it is not obvious that the arms themselves have a large impact on that shifting power balance. Whether the sales do in fact have a significant effect in this regard, moreover, will likely depend heavily on the types of weapons the United States would be willing to sell to Taiwan (and which weapons Taiwan would be willing to buy). For instance, some have suggested that Taiwan's efforts to purchase high-profile and expensive packages such as the F-16C/D fighter are counterproductive given their high cost and the PRC's growing air capabilities; according to these analysts, more mundane (and cheaper) systems are likely to be more effective at countering PRC capabilities. ${ }^{20}$ Whether ending arms sales has a significant effect on $p$ and $c_{c}$, then, will hinge in part on what types of weapons the United States would sell Taiwan if arms sales were to continue.

Likewise, it is not self-evident how large of a signaling effect arms sales have. As we show in the next section, US arms sales send the clearest signal of US support for Taiwan when the sales are costly for the United States to undertake. Yet it is quite clear not only that the sales do not appear to be especially costly for Washington but also that many in the United States actually benefit economically and politically from the sales. When the Obama administration was considering the F-16C/D package in 2011, for instance, a large number of US senators signed a letter to the president urging the sale to go forward; often, the signatories represented states that stood to benefit economically from increased demand for the fighter jets. ${ }^{21}$ In other words, so long as Chinese retaliation against the United States for selling weapons remains limited, the costs of the policy to Washington do not appear especially high. Thus it would not appear to us that arms sales represent an especially strong signal of US commitment to Taiwan, meaning that ending the sales would not necessarily lead Taiwan and China to dramatically alter their assessments of likely US behavior in the event of a cross-Strait conflict.

It is also worth emphasizing that many factors besides US arms sales to Taiwan determine the value of $\mathrm{p}$ and $\mathrm{c}_{\mathrm{c}}$, including Taiwan's indigenous military capabilities, the PRC's capabilities, the level of economic integration across the Taiwan Strait, and so forth. The rapid growth in cross-Strait economic integration and cooperation in recent decades, combined with China's general integration into global markets, for instance, suggests that the costs for China of a cross-Strait military confrontation are probably quite high-even if the PRC would likely win such a confrontation. Compared to these costs, the dent to $c_{c}$ caused by reduced arms sales could actually be quite small.

Finally, and perhaps most importantly, ending arms sales to Taiwan could actually increase $c_{c}$ in some ways. While critics sometimes suggest that ending arms 
sales might simply whet the appetite of China and encourage further demands on the United States, it is also conceivable-as proponents such as Glaser argue-that ending arms sales would lead to significant improvement in the US-China relationship. ${ }^{22}$ Furthermore, whether the United States sells weapons to Taiwan or not, it is hard to imagine a strong and cooperative US-China relationship withstanding PRC coercion against the island. Therefore, if the PRC values a stable US-China relationship, and if ending arms sales to Taiwan does in fact lead to an improved Sino-American relationship, then ending arms sales to Taiwan will also mean that the PRC will have more to lose (in terms of a strong US-China relationship) by initiating conflict in the Taiwan Strait. If this sort of effect outweighs the direct effect of ending arms sales on China's costs of war, then ending arms sales could help to reinforce a stable status quo.

\section{SUMMARY}

In sum, even in the context of our highly stylized and simplified model of crossStrait relations, changes in US policy have complex and uncertain net implications for stability in the Taiwan Strait. Analysts should recognize that ending arms sales to Taiwan could be highly destabilizing: such a change in US policy could help to tip cross-Strait relations from a relatively stable deterrence relationship to an unstable compellence relationship. But ending arms sales will not necessarily have this effect and could actually contribute to stability in the Taiwan Strait by reinforcing China's stake in a stable status quo. It is our hope that our model will help to organize thinking around this important topic, by showing how different types of effects fit together.

\section{WHY A TOUGHER PRC POLICY ON ARMS SALES COULD BACKFIRE}

Just as there have been calls in the United States for a changed US policy on Taiwan arms sales, so have there been calls in Beijing for a changed PRC policy on the issue. ${ }^{23}$ As noted earlier, arms sales to Taiwan provoke an angry response from Beijing. When the United States confirmed a US\$5.8 billion weapons package to Taiwan in 2011, official Chinese media referred to the sale as a "despicable breach of faith in international relations," while one general wrote that the United States was "cheating and making a fool of the Chinese people." ${ }^{24}$ This type of response is not new; in 1992, for instance, the Standing Committee of the National People's Congress issued a statement expressing "extreme indignation over US wanton interference in China's internal affairs" after the Bush administration announced it would sell 150 F-16 fighter jets to Taiwan. ${ }^{25}$ 
Despite the anger that US arms sales to Taiwan typically generate in China, the actual policy response to these sales has typically been muted. Beyond the tough rhetoric, retaliation has been mostly symbolic. For instance, the PRC often responds to arms sales by halting dialogue between the two countries. In recent years, the PRC has temporarily frozen military-to-military dialogues after arms sales decisions. ${ }^{26}$ In 1992, the PRC suspended human rights discussions in response to the F-16 sale. ${ }^{27}$ The PRC has at times hinted at the possibility of a stronger response: in both 1992 and 2010, Chinese officials suggested that the PRC might retaliate with economic sanctions. ${ }^{28}$ Nevertheless, there is little evidence that China has - to date-followed through on these sorts of threats. ${ }^{29}$

China's unwillingness to react more vigorously to US arms sales has led to some frustrations among Chinese analysts and military officials, who have at times advocated a tougher, tit-for-tat response. In early January 2010, Rear Admiral Yang Yi (retired), a prominent defense analyst, called for tougher sanctions against US companies involved in arms sales, and high-profile scholar Shi Yinhong emphasized that China should impose more significant costs on the United States in response to arms sales. ${ }^{30}$ Shortly thereafter, when the US government announced a new weapons sale package for Taiwan in late January, PRC government officials did in fact issue a threat of sanctions (noted above)warning that China would retaliate against Taiwan arms sales by sanctioning US companies involved in the sales. Chinese media quoted several well-known scholars and analysts expressing support for such a policy, including Yang Yi and Beijing University's Wang Yong. ${ }^{31}$ Media reports also suggested widespread support for such a tougher policy among Chinese "netizens." ${ }^{2}$ To be clear, these sorts of sentiments are not new; there have long been voices in China advocating for a tougher PRC response to Taiwan arms sales. John Garver notes, for instance, that military leaders wanted to see a strong response to the 1992 F-16 sale, with some advocating economic sanctions on US exports to China (including agricultural products like wheat). Garver writes that these voices were ultimately overruled by Deng Xiaoping himself. ${ }^{33}$

The rationale for a tougher approach is ultimately twofold. First, a tougher approach would impose higher costs on the United States for pursuing the status quo policy of arms sales to Taiwan. These increased costs could, in turn, lead Washington to reevaluate the utility of the status quo and to conclude that the benefits associated with arms sales no longer justified the costs. Sanctions, in short, have the potential to improve PRC bargaining power in the Taiwan Strait by making it more likely that the United States will scale back its commitment to Taiwan. Second, even if the United States failed to change policy, a tougher approach would at least enable the PRC to signal more clearly - to both domestic and international audiences-its own dissatisfaction with the status quo. As Peking University's Jia 
Qingguo has written, facing "mounting domestic pressure, the [Chinese Communist Party] is finding it increasingly difficult to justify its 'weak' responses, such as verbal protests, to U.S. weapons sales and believes it needs to demonstrate its courage with concrete acts of retaliation." ${ }^{34}$

But a tougher approach to arms sales also entails significant risks for China. Obviously, threatening or imposing sanctions on US companies could further harm the Sino-American relationship and perhaps trigger a trade war. But more fundamentally, consider what happens if the United States continues to sell the weapons even in the face of PRC retaliation. In this case, the weapons sales would become more unambiguously costly for Washington to carry out. By continuing with the sales despite these increased costs, the United States would essentially be signaling a sincere interest in Taiwan's security; it would be much harder to make the argument that US arms sales to Taiwan were motivated by a cynical desire to further the interests of US companies and create a few US jobs. Thus the PRC faces a significant trade-off in responding to US arms sales. To the extent that Chinese policy makers believe that the United States is motivated primarily by cynical economic and political motivations in selling weapons to Taiwan, it makes sense to get tough: the United States would be more likely to back down in such a scenario, and the door would thus open to an end to US arms sales. But to the extent the PRC believes that sincere concerns over Taiwan security enter into US calculations in selling weapons, a tougher policy response could backfire. The United States would be unlikely to back down, and by standing firm in the face of PRC sanctions would signal — to both the PRC and Taiwan - a stronger commitment to the island than was previously evident. The tougher response, moreover, would likely lead to further turbulence in the bilateral Sino-American relationship.

\section{CONCLUSION}

The continuing US commitment to Taiwan's security, and in particular continued US arms sales to Taiwan, represents one of the key sources of tension in the broader Sino-American relationship. In recent years, analysts in both Washington and Beijing have proposed new approaches to the issue. In the United States, some have suggested that the United States end weapons sales to Taiwan and consider backing away from its commitment to the island more broadly. In the PRC, some have suggested that a rising China take a tougher line in response to US arms sales. We have argued that both proposed policy alterations carry with them significant risks. In the US case, ending arms sales to Taiwan could contribute to an increase in the likelihood of conflict in the Taiwan Strait by helping to shift cross-Strait relations from a deterrence dynamic to a compellence dynamic. In the Chinese case, a tougher approach to US arms sales could backfire by revealing a stronger US commitment to Taiwan's security than might be currently assumed. A revealed 
stronger US commitment, in turn, could make Taiwan less willing to accommodate the PRC on sovereignty issues.

\section{NOTES}

1. The act stipulated that the United States would provide Taiwan with "such defense and defense services in such quantity as may be necessary to maintain a sufficient self-defense capability" and that the specific nature of these weapons would be determined by the president and Congress "based solely upon their judgment of the needs of Taiwan, in accordance with procedures established by law." For a discussion of the act and its consequences, see Steven M. Goldstein and Randall Schriver, "An Uncertain Relationship: The United States, Taiwan and the Taiwan Relations Act," China Quarterly, no. 165 (2001): 147-72.

2. For the full text of the communiqué, see "Joint Communiqué on Arms Sales to Taiwan," August 17, 1982, Taiwan Documents Project, www.taiwandocuments.org/communiqueo3.htm. The Reagan administration subsequently interpreted the commitments made by the United States in loose terms, emphasizing that dollars would be inflation adjusted, that quality would be assessed in relative terms, and that the restrictions on arms sales would apply only to weapons and not to technology transfer. See Harry Harding, A Fragile Relationship: The United States and China since 1972 (Washington, DC: Brookings, 1992), 116-17. For a good description of the communiqué, see also Richard C. Bush, At Cross Purposes: U.S.-Taiwan Relations since 1942 (Armonk, NY: M.E. Sharpe, 2004).

3. In 1992, for instance, the United States announced a sale of 150 F-16 fighter jets to Taiwan; the sale exceeded-in quality and quantity-previous weapons sales by a substantial margin. Beijing has frequently protested such perceived US violations of the 1982 communiqué. For detailed discussion, see Zhang Qingmin, "Zhongmei guanxizhong de meiguo shou tai wuqi wenti" [The question of US arms sales to Taiwan in US-China relations], Waijiao Xueyuan Xuebao, no. 1 (1994): 84-92. For a detailed summary and discussion of US arms sales to Taiwan since 1990, see Shirley A. Kan, "Taiwan: Major U.S. Arms Sales since 1990," in Taiwan-U.S. Relations, ed. Samantha E. Marshall (New York: Nova, 2010), $1-75$.

4. Despite the tough rhetoric and symbolic retaliation, the PRC has generally been restrained in its response to US arms sales and has not allowed the issue to derail the broader US-China relationship despite the anger US sales generate in Beijing. See Michael S. Chase, "'Strong Indignation, but Limited Retribution: China’s Response to U.S. Arms Sales to Taiwan," China Brief 11, no. 19 (2011): 3-7. See also the report prepared by the US-Taiwan Business Council and Project 2049 Institute, Chinese Reactions to Taiwan Arms Sales (Arlington, VA: US-Taiwan Business Council and Project 2049 Institute, 2012, https://project2049.net/documents/2012_chinese_reactions_to_taiwan_arms_sales.pdf.

5. "US Sells Weapons to Taiwan, Angering China," Washington Post, January 30, 2010, www.washingtonpost.com/wp-dyn/content/article/2010/01/29/AR2010012904113.html. For a discussion of the role of emotion in China's Taiwan policy (focusing specifically on anger during the 1995-96 Taiwan Strait crisis), see Todd H. Hall, "We Will Not Swallow This Bitter Fruit: Theorizing a Diplomacy of Anger," Security Studies 20, no. 4 (2011): 521-55.

6. Bill Owens, "America Must Start Treating China as a Friend," Financial Times, November 17, 2009, www.ft.com/intl/cms/s/o/69241506-d3b2-11de-8caf-oo144feabdco.html\#axzz2REBX57hW.

7. Charles L. Glaser, "A U.S.-China Grand Bargain? The Hard Choice between Military Competition and Accommodation," International Security 39, no. 4 (2015): 49-9o. See also Charles L. Glaser, "Will China's Rise Lead to War? Why Realism Does Not Mean Pessimism," Foreign Affairs 90, no. 2 (2011): 80-91.

8. Chas W. Freeman Jr., "Beijing, Washington and the Shifting Balance of Prestige," speech delivered at China Maritime Institute, Newport, RI, May 10, 2011, http://chasfreeman.net/576/. 
9. John J. Mearsheimer, "Say Goodbye to Taiwan," National Interest, March-April 2014, http://nationalinterest.org/article/say-goodbye-taiwan-9931. See also Bruce Gilley, "Not So Dire Straits: How the Finlandization of Taiwan Benefits US Security," Foreign Affairs 89, no. 1 (2010): 44-60; Robert Sutter, “Taiwan's Future: Narrowing Straits," National Bureau of Asian Research Analysis, 2011; Ted Galen Carpenter, "Walking a Tightrope: U.S. Arms Sales to Taiwan," Cato Institute, 2011, www.cato. org/publications/commentary/walking-tightrope-us-arms-sales-taiwan. For an excellent summary (and critique) of these arguments, see Richard C. Bush, Uncharted Strait: The Future of China-Taiwan Relations (Washington, DC: Brookings Institute, 2013), chap. 10.

10. See especially Nancy Bernkopf Tucker and Bonnie Glaser, "Should the United States Abandon Taiwan?," Washington Quarterly 34, no. 4 (2011): 23-37; Shelley Rigger, "Why Giving Up Taiwan Will Not Help Us with China," American Enterprise Institute, November 29, 2011, www.aei.org/publication/ why-giving-up-taiwan-will-not-help-us-with-china/; Bush, Uncharted Strait; Douglas H. Paal, "China: Reaction to Taiwan Arms Sales," Carnegie Endowment for International Peace Web Commentary, January 31, 2010, http://carnegieendowment.org/2010/01/31/china-reaction-to-taiwan-arms-sales; T. Y. Wang, "Analyzing the 'Abandoning Taiwan' Argument," paper presented at the American Association for Chinese Studies Annual Meeting, University of Pennsylvania, Philadelphia, 2011. Glaser ("Grand Bargain") himself highlights some of the risks associated with walking away from a commitment to Taiwan.

11. A similar model is developed in Scott L. Kastner, Political Conflict and Economic Interdependence across the Taiwan Strait and Beyond (Stanford, CA: Stanford University Press, 2009); and Scott L. Kastner, "US Rebalancing: Implications for Taiwan's Security and Stability across the Taiwan Strait," in The US Strategic Pivot to Asia and Cross-Strait Relations: Economic and Security Dynamics, ed. Peter C. Y. Chow (New York: Palgrave, 2014), 97-112.

12. We don't assume that the Taiwan leadership's ideal point necessarily lies at I. The current Ma government, for instance, appears to prefer a status quo that leaves open the door to eventual unification over a fully and formally independent Taiwan. It is worth noting, however, that Ma does view the ROC as fully independent and sovereign.

13. The logic of this framework does not hinge on the exact value of $p$. We assume $p$ to be exogenous, as to do otherwise would greatly complicate the model. For works that endogenize the probability of victory within a bargaining framework, see, for instance, James D. Fearon, "Bargaining over Objects That Influence Future Bargaining Power," paper presented at the annual meeting of the American Political Science Association, Washington, DC, August 1996; and Carmen Beviá and Luis C. Corchó, "Endogenous Strength in Conflicts," International Journal of Industrial Organization 31, no. 3 (2013): 297-306.

14. See, for instance, Richard C. Bush and Michael E. O'Hanlon, A War Like No Other: The Truth about China's Challenge to America (Hoboken, NJ: John Wiley and Sons, 2007); Ted Galen Carpenter, America's Coming War with China: A Collision Course over Taiwan (New York: Palgrave, 2005); and Gabe T. Wang, China and the Taiwan Issue: Impending War at the Taiwan Strait (Lanham, MD: University Press of America, 2006). For a more detailed discussion of this and other Taiwan Strait conflict scenarios, see Scott L. Kastner, "Is the Taiwan Strait Still a Flash Point? Rethinking the Prospects for Armed Conflict between China and Taiwan," International Security 40, no. 3 (Winter 2015/16): 54-92. The discussion that follows draws in part from this article.

15. Incentives to misrepresent bargaining power are at the center of Fearon's seminal paper on bargaining failure as a cause of war. Even when there are bargains that both sides prefer to war, incentives to misrepresent one's bargaining leverage make war possible. And even if a state is able to communicate its bargaining leverage to its rival, it is possible for this communication to reduce the probability of bargaining failure only if the act of communication changes the actors' payoffs (e.g., is a costly signal). James D. Fearon, "Rationalist Explanations for War," International Organization 49, no. 3 (1995): 379-414. 
16. Emerson Niou, for instance, shows that a significant majority of Taiwanese would support Taiwan independence if the outcome could be achieved peacefully. See Emerson M. S. Niou, "Understanding Taiwan Independence and Its Policy Implications," Asian Survey 44, no. 4 (2004): 555-67. Recent polls conducted through Taiwan's Election and Democratization Study (TEDS) show that this basic pattern persists. See results online at www.tedsnet.org/.

17. And these, of course, are "big ifs" given the lack of support for unification among Taiwan's citizens. On this lack of support, see for instance polling data from the Election Study Center at National Chengchi University, which can be found online at http://esc.nccu.edu.tw/main.php.

18. For a more extensive discussion along these lines, see Scott L. Kastner and Chad Rector, "Bargaining Power and Mistrust: Credible Commitments and the Prospects for a PRC/Taiwan Agreement," Security Studies 17, no. 1 (2008): 39-71. The discussion here draws in part from that article. For a broader discussion of the dangers of a shift from deterrence to a compellence dynamic in the Taiwan Strait, see Kastner, "Is the Taiwan Strait Still a Flash Point?"

19. Fearon, "Rationalist Explanations."

20. See, for instance, William S. Murray, "Asymmetric Options for Taiwan's Deterrence and Defense," in Globalization and Security Relations across the Taiwan Strait: In the Shadow of China, ed. Ming-chin Monique Chu and Scott L. Kastner (London: Routledge, 2015), 61-79.

21. The text of the letter is available on the webpage of US senator Robert Menendez: "Menendez Urges President Obama to Expedite Sale of Military Aircraft to Taiwan," May 27, 2011, www. menendez.senate.gov/news-and-events/press/menendez-urges-president-obama-to-expeditesale-of-military-aircraft-to-taiwan.

22. Glaser, "Grand Bargain."

23. This section draws from Scott L. Kastner, William L. Reed, and Ping-Kuei Chen, "Mostly Bark, Little Bite? Modeling US Arms Sales to Taiwan and the Chinese Response," Issues and Studies 49, no. 3 (2013): 111-50.

24. “Taiwan Arms Sale Draws Angry, but Familiar, Reaction,” New York Times, September 22, 2011, www.nytimes.com/2011/o9/23/world/asia/china-expresses-anger-over-latest-us-arms-sales-to-taiwan. html.

25. "US Government 'Angrily Condemned' for Taiwan Arms Deal," BBC Summary of World Broadcasts, September 9, 1992 (original source, Xinhua, September 4, 1992).

26. US-Taiwan Business Council, Chinese Reactions; Alastair Iain Johnston, "How New and Assertive Is China's New Assertiveness?" International Security 37, no. 4 (2013): 7-48.

27. "China Apparently Halts Rights Talks with U.S., New York Times, November 25, 1992, A12.

28. On the 1992 episode, see "China Threatens Tariff Retaliation on U.S. Goods," Washington Post September 10, 1992, A9. The article notes that although China's threats were in direct response to punitive tariffs the United States was at the time considering, (unnamed) analysts believed the threats might also have been tied to the recent F-16 decision. On the 2010 episode, see US-Taiwan Business Council, Chinese Reactions.

29. US-Taiwan Business Council, Chinese Reactions.

30. “Zhuanjia: Rang mei geng tongkude ganshoudao sunhai zhongguo liyide daijia” [Expert: Make America more painfully feel the costs of harming China's interests], Xinhua Net, January 8, 2010, http://news.xinhuanet.com/mil/2010-01/o8/content_12776204.htm; "Jiefangjun shaojiang jianyi zhicai meiguo dui tai junshou qiye" [PLA major general recommends sanctioning American companies that sell weapons to Taiwan], Xinhua Net, January 7, 2010, http://big5.xinhuanet.com/gate/big5/news.xinhuanet.com/mil/2010-01/o7/content_12767991.htm.

31. "Sanctions against U.S. Firms Selling Arms to Taiwan Not Violating WTO Rules: Chinese Experts," Xinhua, February 5, 2010.

32. "PRC Public Support Sanctioning US Companies Involved in Arms Sales to Taiwan," Xinhua, February 6, 2010. 
33. John W. Garver, Face Off: China, The United States, and Taiwan's Democratization (Seattle: University of Washington Press, 1997).

34. Jia Qingguo and Alan D. Romberg, "Taiwan and Tibet," in Debating China: The U.S.-China Relationship in Ten Conversations, ed. Nina Hatchigian (New York: Oxford University Press, 2014), 179. 